\title{
Whole Body Nitrogen Kinetics and Their Relationship to Growth in Short Children Treated with Recombinant Human Growth Hormone
}

\author{
DAVID P. DEMPSHER, DENNIS M. BIER, SHERIDA E. TOLLEFSEN, PETER S. ROTWEIN, \\ WILLIAM H. DAUGHADAY, MARY CATHERINE JENSEN, JOHN P. GALGANI, \\ ELLEN HEATH-MONNIG, AND BAKULA TRIVEDI
}

Department of Pediatrics and Department of Internal Medicine, Washington University School of Medicine, St. Louis, Missouri 63110

\begin{abstract}
We studied the effects of growth hormone on retention of ${ }^{15} \mathrm{~N}$-labeled amino acids in 34 short, prepubertal, growth hormone-sufficient children and three growth hormone-deficient subjects. All 34 non-growth hormone-deficient children had apparently normal circulating growth hormone molecules and no mutations were detected in the growth hormone or IGF-I genes of any subjects. Fibroblasts from 34 children responded normally when challenged with recombinant human IGF-I. During the last $72 \mathrm{~h}$ of a 4-d challenge with recombinant human growth hormone $\left(16 \mu \mathrm{g} / \mathrm{kg}\right.$ body wt), retention of a mixed ${ }^{15} \mathrm{~N}$ amino acid dose varied between 5.7 and $50.5 \%$. Whole body protein synthesis, breakdown, and net anabolism calculated from the ${ }^{15} \mathrm{~N}$ kinetics were all increased by the acute growth hormone challenge. However, no routine clinical feature or laboratory determination correlated with the nitrogen retention response. After subsequent treatment $(75 \mu \mathrm{g} / \mathrm{kg}$ three times a week) with recombinant human growth hormone for $1 \mathrm{y}$, there was a significant increase in height velocity, but this increase was not related significantly to pretreatment variables other than inversely to pretreatment height velocity. There was a significant $(p$ $=0.03$ ) correlation between the change in height velocity $\mathrm{Z}$ score and the degree of nitrogen retention to acute challenge with growth hormone, but this correlation was too weak $(r=0.37)$ to be of practical value in predicting the treatment growth response in an individual child. (Pediatr Res 28: 394-400, 1990)
\end{abstract}

\section{Abbreviations}

rhGH, recombinant human growth hormone ANOVA, analysis of variance IRMA, immunoradiometric assay

It is now abundantly clear that some short children whose growth hormone secretion is regarded as normal after provocative stimulation will augment their height velocity significantly when treated with exogenous growth hormone (1-9). One implication of these data is that these children have dysfunctional regulation of growth hormone secretion under physiologic conditions that is masked by pharmacologic provocation. Thus,

Received February 1, 1990; accepted May 8, 1990.

Reprint requests: Dennis M. Bier, M.D., Metabolism Division, Box 8127, Washington University School of Medicine, 660 S. Euclid Avenue, St. Louis, MO 63110 .

Supported in part by grants from the National Institutes of Health HD20805, RR06021, and RR00954, and by a grant from the Eli Lilly Company. there is an increasing need for alternative ways of assessing the physiologic adequacy of a child's growth hormone secretion.

Protein accretion is the sine qua non for growth, and pituitary extracts rich in growth hormone have been known for more than half a century to produce nitrogen retention (10-12). For this reason, before the availability of a growth hormone RIA, improvement in nitrogen balance after growth hormone administration was used routinely for diagnosis of growth hormone deficiency and for assessment of therapeutic response (13-22). Even after the measurement of plasma growth hormone concentration became practical, testing the subject's nitrogen retention response to growth hormone administration remained a clinical and investigative tool (23-38).

${ }^{15} \mathrm{~N}$-labeled amino acids have been used extensively to measure total body nitrogen kinetics in adults and children (39). Unlike classical nitrogen balance studies, studies using ${ }^{15} \mathrm{~N}$-amino acids can be completed in days or, under certain circumstances (40), hours. In addition, with appropriate models, the tracer data allow calculation of whole body protein flux, synthesis, and catabolism, rather than simply net nitrogen balance. Small numbers of short children with growth hormone deficiency have been studied with ${ }^{15} \mathrm{~N}$ techniques in the past $(41,42)$. More recently, Zachmann $e t$ al. (43) used the ${ }^{15} \mathrm{~N}$-retention test to show the biologic equivalency of recombinant and pituitary-derived hGH preparations. Furthermore, Richter et al. (44) reported that the degree of retention of a tracer dose of $\left[{ }^{15} \mathrm{~N}\right]$ glycine induced by growth hormone administration allowed differentiation of children with normal growth hormone secretion from those with complete or partial growth hormone deficiency.

For the above reasons, we postulated that a functional test of growth hormone effect on nitrogen kinetics may provide an index of growth hormone adequacy in short children and, perhaps, predict the response to long-term growth hormone therapy. The results of the test of this hypothesis are described below. A preliminary report of this study (45) and the IGF-I gene characterization (46) have appeared previously.

\section{MATERIALS AND METHODS}

Subjects. Thirty-seven prepubertal children between the ages of 6 and 14 y and more than two SD below the mean height for age were recruited from the Washington University Pediatric Endocrinology Clinic. Their characteristics are summarized in Table 1. Chronic underlying medical illnesses were excluded by history and appropriate conventional diagnostic testing when indicated. All had normal thyroid function. All eight girls had normal karyotypes. The subjects' and parents' heights were measured by trained personnel using a wall-mounted Harpenden stadiometer. Similarly obtained pretreatment height velocity measurements were recorded for a minimum period of $1 \mathrm{y}$ before 
formal enrollment in the study described below. Informed consent was obtained from all families according to procedures approved by the Washington University Human Studies Committee.

Analytical methods. Plasma growth hormone concentrations were quantified by conventional polyclonal RIA, by IM-9 lymphocyte (47) or human liver radioreceptor assay (48), and by two-site monoclonal IRMA (Hybridtech, San Diego, CA). Serum growth hormone binding protein (49) and circulating IGF-I concentration (50) were measured as described previously. Osteocalcin was measured by specific RIA using a commercial antibody (Incstar Corp., Stillwater, MN).

In all subjects, high mol wt chromosomal DNA was isolated from nuclei of peripheral blood cells by standard methods (51). DNA $(10 \mu \mathrm{g})$ was digested individually with restriction endonucleases BamHI, EcoRI, and HindIII, followed by electrophoresis and transfer to nitrocellulose or nylon membranes as described (52). Prehybridization of the membranes, hybridization to a ${ }^{32} \mathrm{P}$ labeled (53) hGH cDNA probe (Genentech, Inc., South San Francisco, CA) and posthybridization washes followed the protocol of Wahl et al. (54). Hybridization bands were detected by autoradiography at $-80^{\circ} \mathrm{C}$ using DuPont Lightening Plus intensifying screens and Kodak XAR5 $\mathrm{x}$-ray film. In addition, each child's IGF-I gene was examined as described (46) and the results have been reported in detail earlier (46). A 2-mm punch biopsy specimen of skin was obtained from 34 of the 37 children for assessment of cultured fibroblast aminoisobutyric acid uptake response to recombinant human IGF-I according to methods detailed previously (55).

Plasma glucose was determined by a glucose oxidase method using the Beckman glucose analyzer, and plasma insulin (56) and urinary C-peptide (57) were measured by polyclonal RIA as described previously. Urinary creatinine, urea, and ammonia were measured by standard methods (40) using commercial kits (Sigma Diagnostics, St. Louis, MO) and urinary total nitrogen

Table 1. Clinical characteristics of patient population*

\begin{tabular}{lcc}
\hline \multicolumn{1}{c}{ Parameter } & $\begin{array}{c}\text { Before GH } \\
\text { treatment } \\
\text { (mean } \pm \mathrm{SD} \text { ) }\end{array}$ & $\begin{array}{c}\text { After 1 y GH } \\
\text { treatment } \\
\text { (mean } \pm \mathrm{SD})\end{array}$ \\
\hline$n$ & 37 & 32 \\
$\mathrm{CA}(\mathrm{y})$ & $8.7 \pm 2.6$ & $9.7 \pm 2.6$ \\
$\mathrm{BA}(\mathrm{y})$ & $6.3 \pm 2.3$ & $7.5 \pm 2.5$ \\
Wt (kg) & $20.2 \pm 5.7$ & $24.6 \pm 7.1$ \\
Ht (cm) & $113.4 \pm 13.5$ & $122.3 \pm 13.6$ \\
Ht (Z score) & $-3.0 \pm 0.7$ & $-2.4 \pm 0.7 \dagger$ \\
Ht velocity (cm/y) & $4.7 \pm 1.2$ & $8.3 \pm 1.6 \dagger$ \\
Ht velocity (Z score for CA) & $-1.4 \pm 1.4$ & $3.1 \pm 2.7 \dagger$ \\
Ht velocity (Z score for BA) & $-1.8 \pm 1.1$ & $2.2 \pm 2.0 \dagger$ \\
RWT predicted ht (cm) & $162 \pm 5.6$ & $164 \pm 6.4$ \\
RWT predicted ht (Z score) & $-3.0 \pm 0.7$ & $-2.4 \pm 0.7 \dagger$ \\
Mother's ht (cm) & $157.4 \pm 5.2$ & \\
Mother's ht (Z score) & $-1.1 \pm 0.9$ & \\
Father's ht (cm) & $173 \pm 7.5$ & \\
Father's ht (Z score) & $-0.5 \pm 1.1$ & \\
\hline
\end{tabular}

${ }^{*}$ Abbreviations: CA, chronologic age; BA, bone age; RWT, RocheWainer-Thissen.

$\dagger p<0.001$ compared with pretreatment value. $\mathrm{CA}, \mathrm{BA}$, wt, and absolute ht were not tested for significance because their increase was dictated by study design and duration. was quantified by chemiluminescence using a nitrogen analyzer (Antek Instruments, Houston, TX). ${ }^{15} \mathrm{~N}$ enrichment in urinary total nitrogen, urea, and ammonia were determined by dualinlet, dual-collector isotope ratio mass spectrometry according to classical methods $(40,58,59)$.

Procedural methods. Before participation in the kinetic study and treatment protocol below, analyses of growth hormone binding protein and the growth hormone and IGF-I genes were carried out in each subject as described above. Plasma growth hormone responses to oral clonidine $(5 \mu \mathrm{g} / \mathrm{kg})$ and i.v. insulin $(0.1 \mathrm{U} / \mathrm{kg})$ provocation were measured in the overnight postabsorptive state. The circulating growth hormone concentration was quantified by polyclonal RIA in all samples. In each provocative test, the two plasma samples in which growth hormone concentration was the highest when measured by polyclonal RIA were remeasured by monoclonal IRMA or by IM-9 or human liver radioreceptor assays as described above.

Nitrogen kinetics. Subsequently, each child was admitted to the Washington University Pediatric Clinical Research Center for $9 \mathrm{~d}$ to study the acute effects of growth hormone administration on nitrogen kinetics. According to a prescription provided by the research dietitian after a diet history, each subject consumed an isocaloric diet containing $1 \mathrm{~g}$ of protein per $\mathrm{kg}$ body wt daily for the week before admission. This procedure was intended to minimize changes in dietary protein intake on admission, when a fully monitored diet containing the same dietary energy and protein intakes was consumed for the entire 9-d hospitalization.

During the hospitalization, blood was drawn each morning in the postabsorptive state and assayed for glucose, insulin, IGF-I, and, on the 4th and 9th days, for osteocalcin as described above. All urine was collected, acidified, and frozen in 8-h aliquots for later analysis of urinary nitrogen end-products and their ${ }^{15} \mathrm{~N}$ enrichments as noted above. On the 2 nd and 6 th hospital days, a dose of mixed ${ }^{15} \mathrm{~N}$-labeled amino acids $\left(1 \mathrm{mg}{ }^{15} \mathrm{~N} / \mathrm{kg}\right.$ body $\left.\mathrm{wt}\right)$ was administered orally with breakfast. The composition of the mixture ( $\mathrm{mg}$ amino acid/ $\mathrm{kg}$ body $\mathrm{wt}$ ) was as follows: leucine 1.007 ; valine 0.901 ; methionine 0.306 ; phenylalanine 0.806 ; lysine 1.007; alanine 0.606; aspartic acid 0.701 ; glutamic acid 0.806 ; glycine 1.007 ; serine 0.507 ; and tyrosine 0.401 .

From the morning of the 5th day until discharge rhGH $(\mathrm{Hu}-$ matrope, Eli Lilly Co., Indianapolis, IN) was injected s.c. every $12 \mathrm{~h}$ at the dose of $16 \mu \mathrm{g} / \mathrm{kg}$ body wt. Urine samples collected for $72 \mathrm{~h}$ as above for nitrogen content and isotopic enrichment on the $2 \mathrm{nd}, 3 \mathrm{rd}$, and $4 \mathrm{th}$, and on the $6 \mathrm{th}$, 7th, and 8th hospital days will be referred to subsequently as the pre- and post-growth hormone samples, respectively.

Growth response. On discharge from the hospital, each child was treated with rhGH (Humatrope) at the dose of $75 \mu \mathrm{g} / \mathrm{kg}$ body wt given three times weekly by s.c. injection. At three monthly intervals over the ensuing 6 to $12 \mathrm{mo}$, each child was reexamined and his/her height measured with a Harpenden stadiometer. If a child failed to exceed his/her pretreatment height velocity by at least $2 \mathrm{~cm} / \mathrm{y}$ at the 6 -mo visit, growth hormone therapy was discontinued. Final examination and height measurement were performed in the remaining "responders" at the 12-mo visit.

Calculations. Total ${ }^{15} \mathrm{~N}$ in each urine sample was calculated as the product of the ${ }^{15} \mathrm{~N}$ enrichment and the total nitrogen content. Cumulative ${ }^{15} \mathrm{~N}$ excretion was the sum of the total urinary ${ }^{15} \mathrm{~N}$ excretion in the pre- and post-growth hormone samples obtained over the $72 \mathrm{~h}$ after administration of the tracer dose. Similarly, cumulative $72-\mathrm{h}\left[{ }^{15} \mathrm{~N}\right]$ urea excretion was calculated from the urinary $\left[{ }^{15} \mathrm{~N}\right]$ urea enrichment and the urinary urea nitrogen content in each sample. Whole body nitrogen and protein kinetic parameters were calculated using established expressions according to the classical, single nitrogen pool model (39).

Values are reported as mean \pm SD. Overall statistical comparisons were made by ANOVA with $t$ test for paired analyses used 
when appropriate. Correlations were calculated by univariate linear regression.

\section{RESULTS}

Clinical characteristics. The clinical characteristics of the subjects are shown in Table 1 . By design, all were prepubertal with a mean age of $8.7 \pm 2.7$ (SD) y and height $Z$ score of $-3.0 \pm 0.7$. On the average, bone age was delayed by slightly more than 2 y and the group, as a whole, had parents whose average heights were shorter than the 50 th percentile height for normally sized adults.

Plasma growth hormone. Twenty-six of the 37 children had a peak plasma growth hormone response of greater than $10 \mathrm{ng} /$ $\mathrm{mL}$ to insulin and/or clonidine provocation. Eight had a peak plasma growth hormone value greater than 7 but less than 10 $\mathrm{ng} / \mathrm{mL}$ to one test but less than $7 \mathrm{ng} / \mathrm{mL}$ to the other test. Three of these eight children had plasma growth hormone values of greater than $10 \mathrm{ng} / \mathrm{mL}$ measured during sleep. Three additional children had peak plasma growth hormone responses less than 7 $\mathrm{ng} / \mathrm{mL}$ to both clonidine and insulin challenge and were classified as growth hormone deficient. None of the latter three had hormonal evidence of additional TSH or ACTH deficiency. Because the subsequent responses of the growth hormone-deficient children to acute and chronic growth hormone supplementation were indistinguishable from those of the remaining 34 subjects, the results for the growth hormone-deficient children will be included with those of the study group as a whole but identified individually when appropriate.

Of the 34 non-growth hormone-deficient subjects, none had a clearly abnormal circulating growth hormone molecule estimated from the ratio of radioreceptor or of monoclonal IRMA assayable growth hormone to the value obtained using conventional polyclonal RIA (45). Thus, the average radioreceptor assay/RIA and IRMA/RIA plasma growth hormone ratios in the selected samples described earlier were $0.97 \pm 0.28$ (SD) and $0.88 \pm 0.22$, respectively, with no value below 0.5 , the 5 th percentile ratio found in subjects of normal height. Similarly, no subject had absent serum growth hormone binding protein (47).

Growth hormone and IGF-I genes. The growth hormone gene locus was analyzed in all 37 subjects and in 10 controls of normal stature by hybridization of a ${ }^{32} \mathrm{P}-$ labeled hGH cDNA to chromosomal DNA digested with three restriction enzymes as described in Methods. A representative autoradiograph of BamHIdigested DNA from eight subjects is illustrated in Figure 1. As indicated, all five genes within the $48-\mathrm{kb}$ cluster are visualized and appear normal in length (53). A similar normal pattern was observed in all subjects with each restriction enzyme. Additionally, the present group of 37 children was included in a previous report of 61 short children who were evaluated for mutations in the IGF-I gene (46). Analysis of chromosomal DNA from these children failed to reveal any variation in the IGF-I gene except for a HindIII site polymorphism present in normally sized individuals as well (46).

Fibroblast responsiveness to IGF-I. All 34 fibroblast cell lines tested for aminoisobutyric uptake response to challenge with recombinant human IGF-I (55) responded normally with a mean $E_{50}$ value of $2.41 \pm 0.71 \mathrm{ng} / \mathrm{mL}$ and a $2.50 \pm 0.40$-fold maximal stimulation of uptake (55).

Nitrogen kinetic response. Daily total urinary nitrogen excretion declined slightly but significantly ( $p<0.05$ by ANOVA) between the 1 st and 2 nd days of hospitalization (Fig. 2) but remained unchanged from the 2 nd through the 4 th days. Growth hormone injections, begun on the 5 th hospital day, induced a second decline in urinary total nitrogen, which achieved a new constant level on d 6 through 8 (Fig. 2). There was no change in the excretion ratios of urea or ammonia to total nitrogen, and creatinine excretion remained unchanged throughout the hospitalization (data not shown).

The total cumulative excretion of ${ }^{15} \mathrm{~N}$ after the first tracer dose

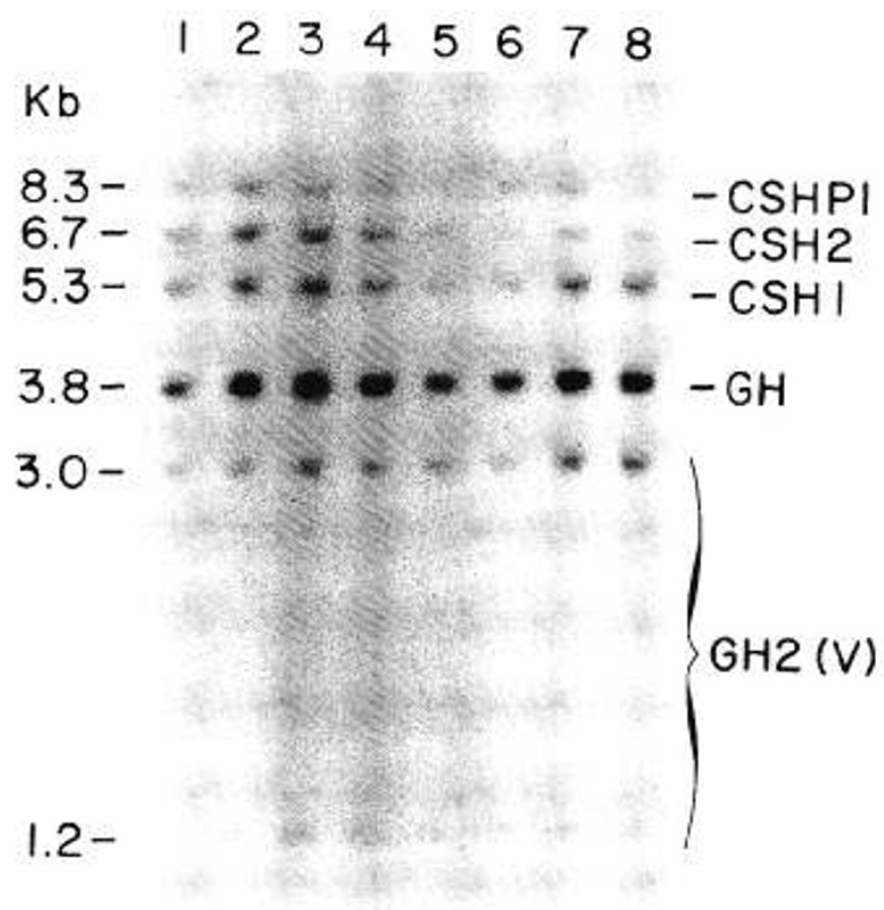

Fig. 1. Analysis of the growth hormone locus in chromosomal DNA from eight short subjects. DNA was digested with BamHI; electrophoresis, transfer to a nylon membrane, and hybridization of ${ }^{32} \mathrm{P}-\mathrm{hGH}$ cDNA were performed as described in Methods. Fragment sizes (kb) and the gene contained within each detected fragment are indicated.

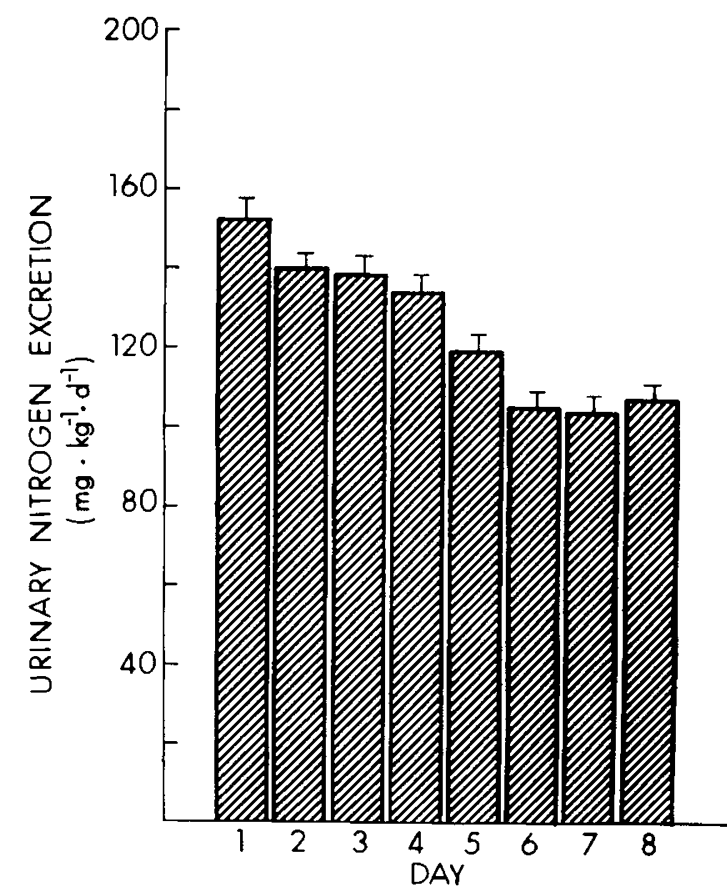

Fig. 2. Total daily urinary nitrogen excretion during the hospitalization for nitrogen kinetic studies. The two mixed ${ }^{15} \mathrm{~N}$ amino acid tracer doses were administered with breakfast on the mornings of $\mathrm{d} 2$ and 6 . Subcutaneous administration of $\mathrm{rGH}$ at 12 -h intervals was begun on the morning of $d 5$ (see text).

(72 $\mathrm{h}$ pre-growth hormone urines) was compared with the cumulative ${ }^{15} \mathrm{~N}$ excretion of the second tracer dose during $72 \mathrm{~h}$ of s.c. growth hormone administration at the dose of $16 \mathrm{~g}$ per $\mathrm{kg}$ body wt every $12 \mathrm{~h}$ (post-growth hormone urines). Before the administration of growth hormone, cumulative ${ }^{15} \mathrm{~N}$ excretion averaged $20.3 \%$ of the dose. During acute supplementation with 
exogenous growth hormone, ${ }^{15} \mathrm{~N}$ excretion declined an average of $31 \pm 10 \%$, but the change varied considerably between subjects, ranging from a 5.7 to a $50.5 \%$ decrease (Fig. 3). The three growth hormone-deficient children diminished their ${ }^{15} \mathrm{~N}$ excretions by $31.5,31.8$, and $50.5 \%$. ANOVA showed no statistically significant relationships between the subjects' clinical characteristics, bone age delay, and IGF-I level and the degree of nitrogen retention after growth hormone administration.

Figure 4 shows the results of whole body protein kinetic parameters calculated from the urinary total nitrogen and total ${ }^{15} \mathrm{~N}$-excretion data as described (39). Before growth hormone treatment, whole body protein turnover, synthesis, and catabolism were $4.38 \pm 0.56,3.52 \pm 0.60$, and $3.38 \pm 0.5 \mathrm{~g} \cdot \mathrm{kg}^{-1} \cdot \mathrm{d}^{-1}$, respectively. Growth hormone challenge increased body protein turnover by enhancing both protein synthesis and protein breakdown (Fig. 4), but because synthesis increased more than breakdown, net body protein accretion (synthesis minus catabolism) increased by more than $200 \%$ from $0.14 \pm 0.03$ to $0.35 \pm 0.02$ $\mathrm{g} \cdot \mathrm{kg}^{-1} \cdot \mathrm{d}^{-1}(p<0.001)$.

Growth hormone challenge at $16 \mu \mathrm{g} / \mathrm{kg}$ every $12 \mathrm{~h}$ caused an increase in the postabsorptive serum IGF-I level from a pregrowth hormone value of $0.56 \pm 0.48$ to $0.97 \pm 0.56 \mathrm{U} / \mathrm{mL}$ by the morning of the 4 th day of treatment, significant at the $p<$ 0.05 level by ANOVA. By similar analysis, there was no relationship between any of the whole body protein kinetic indices derived from the ${ }^{15} \mathrm{~N}$-tracer data and the change in circulating IGF-I. The acute 4-d treatment with rhGH caused no change in circulating growth hormone binding protein and no significant change was observed in fasting plasma glucose or insulin values (Fig. 5a) during the period of growth hormone challenge. How-

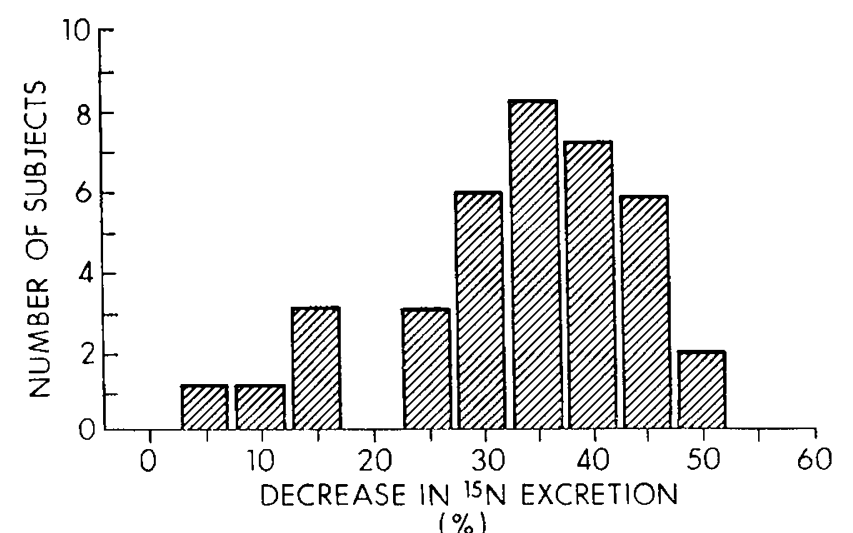

Fig. 3. Distribution of the percent change in excretion of the mixed ${ }^{15} \mathrm{~N}$ amino acid tracer dose by the study subjects during $72 \mathrm{~h}$ of growth hormone treatment.

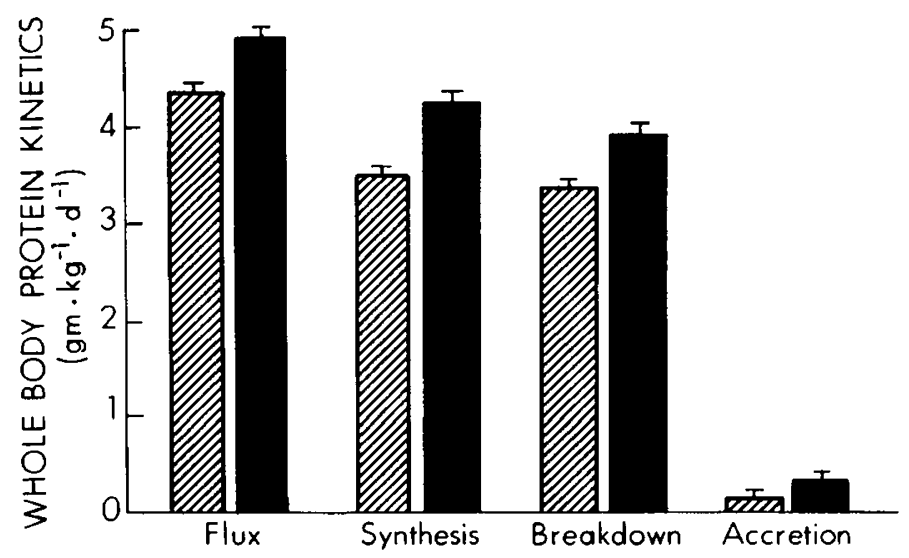

Fig. 4. Whole body protein turnover, synthesis, breakdown, and net protein accretion (synthesis minus breakdown) in the study subjects before and during $72 \mathrm{~h}$ of growth hormone treatment. ever, daily urinary C-peptide excretion (Fig. $5 b$ ) rose significantly $(p<0.05)$ within $24 \mathrm{~h}$ of growth hormone administration and stayed elevated throughout the remaining period of growth hormone treatment. Serum osteocalcin was $11.8 \pm 2.0 \mathrm{ng} / \mathrm{mL}$ before growth hormone supplementation and remained unchanged after $4 \mathrm{~d}$ of $\mathrm{rhGH}$ injections. In no individual was there a substantial change in serum osteocalcin.

Growth response. Of the 37 subjects who had their nitrogen kinetic responses measured, one dropped out of the study before the 3-mo visit and one voluntarily discontinued follow-up at 9 mo of therapy. Data from these two subjects are excluded from discussion of long-term response to growth hormone treatment. At the 6-mo treatment visit, growth hormone treatment of three children was discontinued because their height velocities had not increased by more than $2 \mathrm{~cm} / \mathrm{y}$ above their pretreatment height velocity values. The complement of this observation is that 33 of the 36 individuals who were treated with growth hormone for 6 mo grew at an accelerated rate. Of the 32 children who completed a full year of treatment, two girls developed breast buds by 1 y of therapy. Their data are included in subsequent analyses because pubertal progression was minimal and exclusion of their data had no effect on the statistical analyses that follow. No adverse effects were detected during the prolonged growth hormone treatment. We observed no significant changes in postabsorptive blood glucose, cholesterol, or triglyceride values measured by routine clinical chemistry assays. There was no significant rise in antibody titers to Escherichia coli proteins or to growth hormone as measured by the standardized assays at the Eli Lilly Company.

Table 1 shows the growth parameters for the 32 children at the end of a year's treatment with rhGH at the dose of $75 \mu \mathrm{g} / \mathrm{kg}$ body wt administered s.c. three times a week. Despite the fact that incremental annualized height velocity declined to less than $2.0 \mathrm{~cm} / \mathrm{y}$ over pretreatment height velocity in an additional six children during the 2 nd 6 mo of growth hormone treatment, the measured yearly posttreatment height velocity of the group as a whole was still significantly elevated at $8.3 \pm 1.6 \mathrm{~cm} / \mathrm{y}(p<$ 0.001 ), a comparison maintained as well for height velocity $Z$ scores expressed for both chronologic and bone ages (Table 1). The three growth hormone-deficient subjects increased their absolute height velocities by $2.6,6.3$, and $9.2 \mathrm{~cm} / \mathrm{y}$ and their height velocity $Z$ scores by $3.8,8.7$, and 12.8 .

The average height of the subject group increased from 113.4 to $122.3 \mathrm{~cm}$, representing a significant $(p<0.05)$ mean change in height $\mathrm{Z}$ score of $+0.64 \pm 0.33$. The ratio of the change in bone age to the change in chronologic age averaged $1.3 \pm 0.8$, a value not statistically different from 1.0 by $t$ test. Predicted adult height increased, but not significantly (Table 1). Neither pretreatment IGF-I nor the acute change in IGF-I to growth hormone challenge predicted the long-term growth response. Only a low pretreatment height velocity correlated significantly with the change in annualized growth rate at $1 \mathrm{y}$ of treatment $(r=-0.6$, $p<0.001)$.

Neither the measured growth rates nor the increments in height velocity above pretreatment values (when expressed in absolute terms of $\mathrm{cm} / \mathrm{y}$ ) at 3,6 , or $12 \mathrm{mo}$ of therapy were correlated with any of the indices of protein dynamics derived from the ${ }^{15} \mathrm{~N}$ data, including the percent change in ${ }^{15} \mathrm{~N}$ excretion itself. Figure 6 shows the relationships between the change in ${ }^{15} \mathrm{~N}$ retention induced by the acute growth hormone challenge and the increment above pretreatment height velocity measured after $1 \mathrm{y}$ of treatment with $\mathrm{rhGH}$. When the change in height velocity measured after $1 \mathrm{y}$ of $\mathrm{rhGH}$ treatment was expressed as a $\mathrm{Z}$ score to normalize for age-related differences in growth rate, there was a weak but significant correlation $(r=0.37, p=0.03)$ with the change in ${ }^{15} \mathrm{~N}$ retention to the acute growth hormone challenge (Fig. 6). Obviously, for an individual subject, this relationship was too weak to be predictive of height velocity response to growth hormone treatment. 

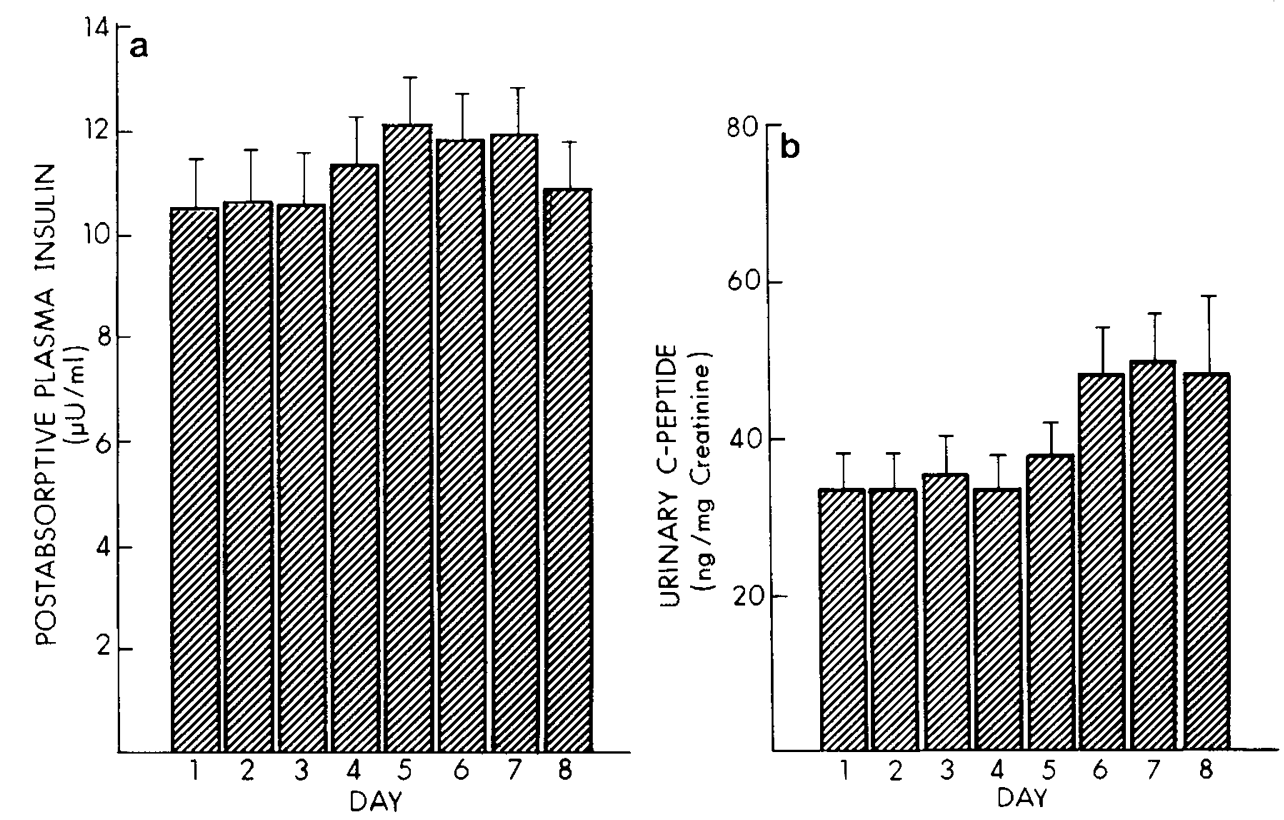

Fig. 5. $a$, Postabsorptive plasma insulin values during the hospitalization for nitrogen kinetic studies. $b$, Twenty-four $\mathrm{h}$ urinary C-peptide excretion over the same period. Growth hormone administration was begun on the morning of $\mathrm{d} 5$ (see text).

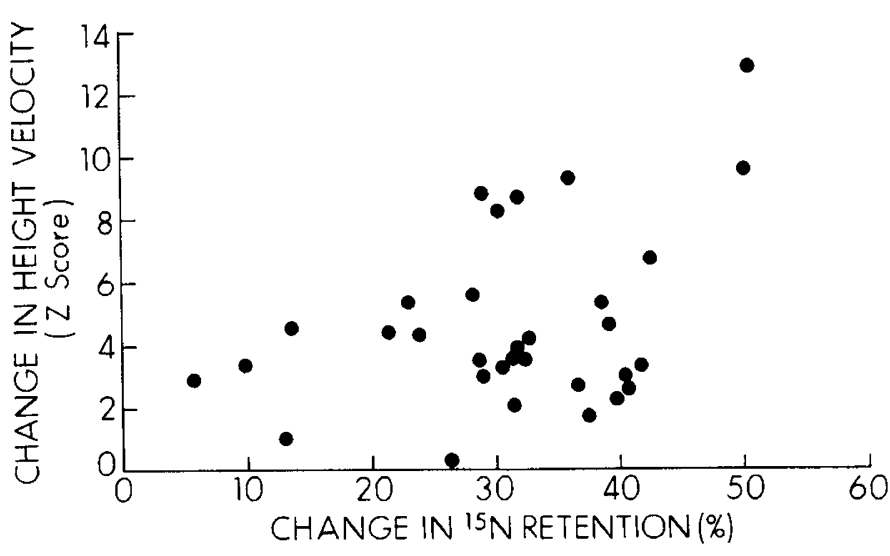

Fig. 6. Relationship between the change in nitrogen retention to an acute challenge with growth hormone and the change in ht velocity at the end of $1 \mathrm{y}$ of treatment with $\mathrm{rhGH}$, expressed as change in height velocity $\mathrm{Z}$ score for age. This relationship is defined by the equation $\mathrm{y}=$ $0.15 \mathrm{x} \pm 1.4(r=0.37)$ and is significant at the $p=0.03$ level.

\section{DISCUSSION}

In our study, the acute metabolic response to growth hormone was tested in a group of 34 short children whose growth hormone secretion was normal after challenge with conventional provocative stimuli and three children who met the classical criteria of growth hormone deficiency. Subsequently, all were treated with rhGH for 6 mo to 1 yr. Thirty-two children completed a year's therapy.

The study population was well characterized. In addition to conventional clinical assessment and routine measurements of bone age, growth hormone secretion, and circulating IGF-I, the subjects' growth hormone and IGF-I genes (46) were shown to be normal. There was no gross structural abnormality of the circulating growth hormone molecule as probed by radioreceptor and monoclonal antibody assays $(47,48)$. No child had absent growth hormone receptors as assessed by assaying circulating growth hormone binding protein levels (49). Each subject's cultured fibroblasts were normally sensitive to IGF-I with regard to uptake of aminoisobutyric acid (55).

As in other reports (1-9), we showed that a significant per- centage of children who had apparently normal growth hormone secretion will augment their height velocity significantly when treated with exogenous growth hormone. Thirty-three of the 36 subjects treated for 6 mo grew at a height velocity $2.0 \mathrm{~cm} / \mathrm{y}$ or more greater than their pretreatment rate. Of the 32 subjects completing a year of growth hormone treatment, 29 had grown a measured annual height velocity of $2.0 \mathrm{~cm}$ or more faster than the pretreatment rate and half grew $3.0 \mathrm{~cm}$ or more faster than their pretreatment height velocity. On average, the children's height velocity was $77 \%$ faster after 1 y of treatment with $\mathrm{rhGH}$, $8.3 \pm 1.6$ versus $4.7 \pm 1.2 \mathrm{~cm} / \mathrm{y}$ (Table 1$)$. These results are similar to previous studies in other groups (7-9).

Consistent with the reports of others $(7,8)$, and except for the inverse correlation with the child's pretreatment height velocity also shown by Lin et al. (7), we were unable to find any correlation between anthropometric parameters, bone age, or circulating growth hormone levels achieved after provocative testing and subsequent growth response to treatment. In contrast to the largest study reported to date (8), we were also unable to find a relationship between the child's pretreatment serum IGF-I concentration and subsequent growth response to treatment or to calculate significantly improved prediction of final adult height. Others have also failed to find the former relationship (7) or the latter apparent improvement (9). Nor did we find a relationship between the acute changes in serum IGF-I and subsequent growth, consistent with the data of Gertner et al. (4).

In an attempt to provide a more physiologic predictor of growth response to chronic growth hormone treatment, we assessed the child's nitrogen retention response to an acute challenge with growth hormone and quantified whole body nitrogen and protein kinetics using ${ }^{15} \mathrm{~N}$-labeled amino acids. The former approach is not new (13-38) but the latter method has been little used (41-44). Its potential advantages are several. In particular, however, is the advantage that addition of the tracer allows one to distinguish between an increase in protein synthesis and a decrease in protein breakdown as the mechanism of reduced nitrogen excretion after growth hormone administration. For this purpose, we used a mixture of ${ }^{15} \mathrm{~N}$-labeled essential and nonessential amino acids rather than the more commonly used $\left.{ }^{15} \mathrm{~N}\right]$ glycine in an attempt to label the nitrogen pool more uniformly. Because glycine constitutes about $1 / 3$ the composition of collagen, collagen itself represents about $20-25 \%$ of total body protein, and growth hormone's effects on collagen (60) might 
not reflect its actions on body protein synthesis as a whole, we elected to avoid potential bias introduced by using this amino acid singly as a tracer.

On the average, growth hormone enhanced ${ }^{15} \mathrm{~N}$ retention by $31 \%$, but the variability in the nitrogen response to rhGH was striking (range 5.7-50.5\%) considering that the subjects were on the same reasonably constant dietary protein intake for $8 \mathrm{~d}$ before the first tracer study. Richter et al. (44) found a similar variability using $\left[{ }^{15} \mathrm{~N}\right]$ glycine tracer. However, in contrast to Richter et al. (44), we were unable to find a relationship between a child's growth hormone status determined with provocative testing and the child's ${ }^{15} \mathrm{~N}$ retention after growth hormone challenge. Thus, for example, two of the three children who failed both growth hormone provocative tests had ${ }^{15} \mathrm{~N}$ retention responses virtually identical to the mean value. This result is also decidedly different from several earlier studies $(23,25,27,29$, $30,32,61)$ where children with growth hormone deficiency had distinctly greater reductions in urinary nitrogen excretion than children who were not deficient in this hormone.

The ${ }^{15} \mathrm{~N}$ tracer allowed us to show for the first time in a large, well-defined group of short children that the growth hormoneinduced decrease in nitrogen excretion is not the result of decreased protein breakdown. Body protein breakdown, in fact, increased, but less so than synthesis. Thus, there was a net anabolic effect. Presumably, the increase in body protein breakdown reflects the necessary remolding of body structural proteins necessary for growth. These data complement the recent report of Dahms et al. (62) who showed, under similar circumstances in a group of growth hormone-deficient children, that growth hormone administration produced a decrease in urea synthesis Because the latter authors concluded that the decline in urea production reflected decreased production of ureogenic substrates by peripheral tissues, we might postulate that the increased amino acid supply generated via augmented protein breakdown found in our study is reused locally for protein synthesis.

All of our subjects underwent a therapeutic trial with rhGH at a dose of $75 \mu \mathrm{g} / \mathrm{kg}$ given three times a week. There are limited systematic data available on growth hormone secretory rates in childhood. Based on the recently published data of AlbertssonWikland et al. (63), the growth hormone treatment doses used in our study were within the normal secretory range for children of the same height and pubertal status. Based on similar data recently reported by Rosenbaum and Gertner (64), the treatment dose used in our study may have been as high as three times the child's usual secretory rate.

The response to therapy was highly variable with the change in height $Z$ score ranging from 0 to +1.6 after $1 \mathrm{y}$ of treatment with $\mathrm{rhGH}$. The two children with the greatest increase in nitrogen retention had the greatest increment in height velocity $Z$ score at 1 y (Fig. 6). All seven children whose height velocity $Z$ scores increased by more than 6 had a greater than $25 \%$ decline in ${ }^{15} \mathrm{~N}$ excretion. The two children with decrements in ${ }^{15} \mathrm{~N}$ excretion less than $10 \%$ increased their growth rate $\mathrm{Z}$ score by less than 4 . On the other hand, most children showed a greater than $25 \%$ decrease in ${ }^{15} \mathrm{~N}$ excretion but increased their height velocity $Z$ scores by less than 4 (Fig. 6). Thus, overall, the weak but significant correlation demonstrated between ${ }^{15} \mathrm{~N}$ retention and height velocity $Z$ score is not a useful predictor of height velocity response for individual subjects.

There may be several reasons for the lack of demonstrated correlation. First, the children received a fixed dose of growth hormone for the acute challenge. Based on the recently reported growth hormone secretion rates mentioned above $(63,64)$, this dose may have represented a variable stimulus to nitrogen retention depending on the magnitude of the child's own prior endogenous secretory rate. Similarly, growth hormone may have induced a variable degree of insulin resistance, both with regard to its effects on amino acid metabolism and in reference to its role in carbohydrate homeostasis. The almost immediate increase seen in urinary C-peptide excretion supports the rapid develop- ment of some decline in tissue sensitivity to insulin. On the other hand, it is likely that more long-term adaptive and accommodative changes in fuel metabolism induced by chronic growth hormone treatment superceded any temporary acute effects of growth hormone on nitrogen kinetics. In addition to alterations in insulin sensitivity mentioned above, these include alterations in energy intake and/or expenditure, as well as peripheral adipose tissue lipolysis. Only serial studies of the kinetics of amino acid, glucose, and lipid fuels before and during growth hormone supplementation can help resolve these issues.

In conclusion, 37 short children exhibited dramatic but highly variable changes in body protein kinetics in response to a short course of growth hormone that increased whole body protein turnover, synthesis, and breakdown. The growth rate increments in response to long-term growth hormone treatment were also variable and were not predictable from the acute nitrogen kinetic changes induced by growth hormone administration. Presumably, this variability is due to physiologic mechanisms that regulate body nitrogen economy during growth. Understanding the mechanisms responsible for the variability will provide insight into the relationships between metabolic fuel transport, energy balance, and protein dynamics and their regulation by growth hormone in growing children.

Acknowledgment. The authors thank E. Y. Chen of Genentech, Inc. for providing the hGH cDNA.

\section{REFERENCES}

1. Rudman, D, Kutner MA, Blackstone RD, Cushman RA, Bain RP, Patterson PH 1981 Children with normal-variant short stature: treatment with human growth hormone for six months. N Engl J Med 319:238-241

2. Plotnick LP, Van Meter QL, Kowarski AA 1983 Human growth treatment of children with growth failure and normal growth hormone levels by immunoassay: lack of correlation with somatomedin generation. Pediatrics 71:324-327

3. Van Vliet G, Styne DM, Kaplan SL, Grumbach MM 1983 Growth hormone treatment for short stature. N Engl J Med 309:1016-1022

4. Gertner JM, Genel M, Gianfredi SP, Hintz RL, Rosenfeld RG, Tamborlane WV, Wilson DM 1984 Prospective clinical trial of human growth hormone in short children without growth hormone deficiency. $J$ Pediatr 104:172176

5. Albertsson-Wikland K 1986 Growth hormone treatment in short children. Acta Paediatr Scand 325S:64-70

6. Bierich JR 1986 Treatment by hGH of constitutional delay of growth and adolescence. Acta Paediatr Scand 325S:71-75

7. Lin TH, Kirkland RT, Sherman BM, Kirkland JL 1989 Growth hormone short children and their response to growth hormone therapy. J Pediatr 115:57-62

8. Genentech Collaborative Study Group 1989 Idiopathic short stature: results of a one-year controlled study of human growth hormone treatment. J Pediatr 115:713-718

9. Dutch Growth Hormone Working Group 1989 Effects of two years of methionyl growth hormone therapy in two dosage regimens in prepubertal children with short stature, subnormal growth rate, and normal growth hormone response to secretagogues. J Pediatr 115:720-725

10. Teel HM, Watkins O 1924 The effect of extracts containing the growth principle of the anterior hypophysis upon the blood chemistry of dogs. Am J Physiol 89:662-669

11. Teel HM, Cushing H 1930 Studies in the physiological properties of the growthpromoting extracts of the anterior hypophysis. Endocrinology 14:157-164

12. Gaebler OH 1933 Some effects of anterior pituitary extracts on nitrogen metabolism, water balance, and energy metabolism. J Exp Med 57:349-354

13. Beck JC, McGarry EE, Dyrenfurth I, Venning EH 1957 Metabolic effects of human and monkey growth hormone in man. Science 125:884-886

14. Beck JC, McGarry EE, Dyrenfurth I, Venning EH 1958 The metabolic effects of human and monkey growth hormone in man. Ann Intern Med 49:1090

15. Ikkos D, Luft R, Gemzell CA 1958 The effect of human growth hormone in man. Lancet 1:720-723

16. Medical Research Council 1959 The effectiveness in man of human growth hormone. Lancet 1:7-8

17. Hutchings JJ, Escamilla RF, Deamer WC, Li CH 1959 Metabolic changes produced by human growth hormone (LI) in a pituitary dwarf. $J$ Clin Endocrinol Metab 19:759-765

18. Henneman PH, Forbes AP, Moldawer M, Dempsey EF, Carroll EF 1960 Effects of human growth hormone in man. J Clin Invest 39:1223-1228

19. Bergenstal DM, Lipsett MB 1960 Metabolic effects of human growth hormone and growth hormone of other species in man. $\mathrm{J}$ Clin Endocrinol Metab 20:1427-143

20. Shepard TH, Nielsen RL, Johnson ML, Bernstein N 1960 Human growth 
hormone. I. Metabolic balance studies carried out in a hypopituitary child. Am J Dis Child 99:90-95

21. Shepard TH, Waxman S, Bernstein N, Ferrier P 1960 Human growth hormone. II. Further study of its effect on growth in dwarfism. J Pediatr 57:363-369

22. Henneman PH, Henneman DH 1960 Human growth hormone. Diabetes 9:272-276

23. Prader A, Illig R, Szeky J, Wagner H 1964 The effect of human growth hormone in hypopituitary dwarfism. Arch Dis Child 39:535-540

24. Laron Z 1967 Dwarfism, hypopituitarism, and growth hormone. Arch Dis Child 42:225-231

25. Prader A, Zachmann M, Poley JR, Illig R 1968 The metabolic effect of a small uniform dose of human growth hormone in hypopituitary dwarfs and in control children. Acta Endocrinol 57:115-119

26. Wright JC, Brasel JA, Aceto T, Finkelstein JW, Kenny FM, Spaulding JS, Blizzard RM 1965 Studies with human growth hormone (hGH). Am J Med 38:499-503

27. Hubble D 1966 Studies with human growth hormone. Arch Dis Child 41:1722

28. Melvin KEW, Wright AD, Hartog M, Antcliff AC, Copestake AM, Fraser TR 1967 Acute metabolic response to human growth hormone in different types of dwarfism. Brit Med J 3:196-199

29. Brown GA, Stimmler L, Lines JG 1967 Growth hormone-induced nitrogen retention in children of short stature. Arch Dis Child 42:239-244

30. Clayton BE, Tanner JM, Vince FP 1971 Diagnostic and prognostic value of short-term metabolic response to human growth hormone in short stature. Arch Dis Child 46:405-411

31. Grunt JA, Enriquez AR 1972 Acute and long-term responsiveness to growth hormone in children with short stature. Pediatr Res 6:664-668

32. Joss EE 1975 Growth hormone deficiency in childhood. In: Monographs in Pediatrics, Vol 5. S. Karger, Basel, pp 123-139

33. Rudman D, Chyatte SB, Patterson JH, Gerron GG, O'Beirne I, Barlow J, Ahmann P, Jordan A, Mosteller RC 1971 Observations on the responsiveness of human subjects to human growth hormone. J Clin Invest 50:1941-1948

34. Rudman D, Kutner MH, Fleming GA, Harris RC, Kennedy EE, Bethel RA, Priest JH 1978 Effect of 10-day courses of human growth hormone on height of short children. J Clin Endocrinol Metab 46:28-34

35. Rudman D, Kutner MH, Blackston RD, Jansen RD, Patterson JH 1979 Normal variant short stature: subclassification based on responses to exogenous human growth hormone. J Clin Endocrinol Metab 49:92-97

36. Rudman D, Kutner MH, Goldsmith MA, Kenny J, Jennings H, Bain RP 1980 Further observations on four subgroups of normal variant short stature. $J$ Clin Endocrinol Metab 51:1378-1384

37. Joss EE, Zuppinger KA 1972 The significance of intermediate plasma growth hormone levels in growth-retarded children. J Pediatr 81:1092-1098

38. Butenandt O, Bidlingmaier F, Knorr D 1974 Effect of different human growth hormone preparations on nitrogen retention in hypopituitary children. Acta Paediatr Scan 63:549-554

39. Waterlow JC, Garlick PJ, Millward DJ 1978 Protein Turnover in Mammalian Tissues and in the Whole Body. North-Holland Publishing Company, Amsterdam

40. Fern EB, Garlick PJ, McNurlan MA, Waterlow JC 1981 The excretion of isotope in urea and ammonia for estimating protein turnover in man with $\left[{ }^{15} \mathrm{~N}\right] \mathrm{glycine}$. Clin Sci 61:217-228

41. Zafar MS, Mellinger RC, Wolf C, Morrow LB, Whitten C, DeJongh D, Hills E 1974 Nitrogen metabolism in growth hormone-deficient children receiving oxandrolane and human growth hormone. Metabolism 23:239-247

42. Zachmann M, Zagalak M, Gitzelmann RP, Prader A 1979 Modification of $15 \mathrm{~N}$ balance by growth hormone, testosterone, and thyroxine in patients with growth-hormone deficiency and hypothyroidism. In: Klein ER, Klein PD (eds) Stable Isotopes: Proceedings of the Third International Conference. Academic Press, New York, pp 619-658

43. Zachmann M, Kempken B, Frisch H, Fiser I 1988 Effect of a recombinant human growth hormone preparation on the urinary ${ }^{15}$ Nitrogen balance in growth-hormone-deficient children. Horm Res 29:140-142

44. Richter I, Heine W, Plath C, Mix M, Wutzke KD, Towe J $1987{ }^{15} \mathrm{~N}$ tracer techniques for the differential diagnosis of dwarfism and prediction of growth hormone action in children. J Clin Endocrinol Metab 65:74-77

45. Dempsher DP, Tollefsen SE, Heath-Monnig E, Trivedi B, Gavin III JR Daughaday WH, Bier DM 1988 Assessing selected aspects of adequacy of the growth hormone-somatomedin axis in short children with quantitatively normal growth hormone secretion. In: Bercu BB (ed) Basic and Clinical Aspects of Growth Hormone. Plenum Press, New York, pp 263-270

46. Lajara R, Galgani Jr JP, Dempsher DP, Bier DM, Rotwein P 1990 Low prevalence of insulin-like growth factor-I gene mutations in human growth disorders. J Clin Endocrinol Metab 70:687-692

47. Frazer T, Gavin JR, Daughaday WH, Hillman RE, Weldon VV 1982 Growth hormone-dependent growth failure. J Pediatr 101:12-15

48. Daughaday WH, Trivedi B, Winn HN, Yan H 1990 Hypersomatotropism in pregnant women, as measured by a human liver radioreceptor assay. $\mathrm{J}$ Clin Endocrinol Metab 70:215-221

49. Daughaday WH, Trivedi B 1987 Absence of serum growth hormone binding protein in patients with growth hormone receptor deficiency (Laron dwarfism). Proc Natl Acad Sci USA 84:4636-4640

50. Scott MG, Cuca GC, Petersen JR, Lyle LR, Burleigh BD, Daughaday WH 1987 Specific immunoradiometric assay of insulin-like growth factor I with use of monoclonal antibodies. Clin Chem 33:2019-2023

51. Blin N, Stafford DW 1976 A general method for isolation of high molecular weight DNA for eukaryotes. Nucleic Acids Res 3:2302-2308

52. Southern EM 1975 Detection of specific sequences among DNA fragments separated by gel electrophoresis. J Mol Biol 98:503-517

53. Vnencak-Jones CL, Phillips III JA, Chen EY, Seeburg PH 1988 Molecular basis for human growth hormone gene deletions. Proc Natl Acad Sci USA 85:5615-5619

54. Wahl GM, Stern N, Stark GR 1979 Efficient transfer of large DNA fragments from agarose gels to diazobenzyloxymethyl-paper and rapid hybridization by using dextran sulfate. Proc Natl Acad Sci USA 76:3683-3687

55. Heath-Monnig E, Wohltmann HJ, Mills-Dunlap B, Daughaday WH 1987 Measurement of insulin-like growth factor I (IGF-I) responsiveness of fibroblasts of children with short stature: identification of a patient with IGF-I resistance. J Clin Endocrinol Metab 64:501-507

56. Hales C, Randle R 1963 Immunoassay of insulin with insulin antibody precipitate. Biochem J 88:137-146

57. Kuzuya H, Blix PM, Horwitz DL, Steiner DF, Rubenstein AH 1977 Determination of free and total insulin and C-peptide in insulin treated diabetics. Diabetes 26:22-29

58. Matthews DE, Conway JM, Young VR, Bier DM 1981 Glycine nitrogen metabolism in man. Metabolism 30:886-893

59. Steffee WP, Goldsmith RS, Pencharz PB, Scrimshaw NS, Young VR 1976 Dietary protein intake and dynamic aspects of whole body nitrogen metabolism in adult humans. Metabolism 52:281-297

60. August GP, Hung W, Houck JC 1974 The effects of growth hormone therapy on collagen metabolism in children. J Clin Endocrinol Metab 39:1 103-1109

61. Knorr D, Butenandt O 1967 Erfahrungen mit dem Stickstoff-Retentionstest mit humanem, hypophysärem Wachstumshormon (HGH) nach Prader be verschiedenen Formen des Zwergwuchses. Monatsschr Kinderheilkd 115:308-309

62. Dahms WT, Owens RP, Kalhan SC, Kerr DS, Danish RK 1989 Urea synthesis nitrogen balance, and glucose turnover in growth-hormone-deficient children before and after growth hormone administration. Metabolism 38:197-203

63. Albertsson-Wikland K, Rosberg S, Libre E, Lundberg LO, Groth $\Upsilon 1989$ Growth hormone secretory rates in children as estimated by deconvolution analysis of 24-h plasma concentration profiles. Am J Physiol 257:E809E814

64. Rosenbaum M, Gertner JM 1989 Metabolic clearance rates of synthetic human growth hormone in children, adult women, and adult men. J Clin Endocrinol Metab 69:821-824 